\title{
Industrial Policy and the Development of the Electric Vehicles Industry: The Case of Korea
}

\author{
Euna Lee ${ }^{1}$, Jai S. Mah ${ }^{2}$
}

\begin{abstract}
The Korean government has stimulated R\&D activities of the electric vehicle (EV) industry and promoted commercialization of EVs. Korea's EV industry developed rapidly. The industrial policy to promote the EV industry provides implications to the automobile producers. First, producers not developing EV technologies may lag behind in the market. Second, it is important to improve the efficiency of their R\&D expenditures. Third, it may be effective for the less advanced EV producers to cooperate with foreign producers. Fourth, the EV producers are needed to cooperate with the rechargeable battery producers. Fifth, success of the EV industry will depend on the probability of reducing the production cost. Sixth, the government should prepare R\&D support measures targeting promotion of SMEs in the EV industry. Seventh, the government wishing to promote the EV industry needs to define the responsibility of each Ministry and establish a system resolving conflicts between the Ministries efficiently.
\end{abstract}

Keywords: electric vehicles, Korea, industrial policy, environment

Submitted: August 7 $7^{\text {th }}, 2020$ / Approved: December 21st, 2020

\section{Introduction}

Automobile industry has attracted a particular attention from policymakers due to its linkage to various other industries in addition to its role in employment generation, technological development and contribution to national income. The rising production of automobiles has been accompanied by growth of the world economy. Production of automobiles increased from 58.3 million in 2000 to 77.6 million in 2010 and then to 95.7 million cars in 2018 (International Organization of Motor Vehicle Manufacturers, 2018). Automobile production had traditionally been led by developed countries, while several developing countries such as China, India, Korea and Mexico began to be the large automobile producers. China became the largest automobile producer in the world economy as a whole, and in 2018, Korea was ranked as the sixth largest producer of automobiles, exporting threefifths of its automobiles (Statistics Korea, 2019a).

Recently, major producers of automobiles are focusing on the increasing production of eco-friendly vehicles in the process of overcoming the global warming phenomenon. Due to such global efforts of producing eco-friendly vehicles, worldwide stock of new energy vehicles (NEVs) consisting of Plug-in Hybrid Electric Vehicle (PHEV) and Electric Vehicle (EV) increased significantly from 7,500 units in 2009 to 1.3 million units in 2015 and to 5.1 million units in 2018 (International Energy Agency, 2019).

Along with the growing concern for world-wide environmental issues such as global warming, Korea is suffering from high level of greenhouse gas emission and fine particulate matter caused partly by its large manufacturing sector which generates high level of pollution. Korea's energy mix is dominated by fossil fuel, with more than 20 percent of fossil energy used in transportation sector, and has the lowest share of renewable energies among the OECD members. To alleviate such issues, the Korean government established policies to promote green growth and aimed to reduce greenhouse gas emissions by 37 percent or below by 2030 (Hwang, 2015; OECD, 2017: 14-15).

One of Korea's green growth efforts is the development of eco-friendly NEVs (Ministry of Environment (MOE), 2014). Korea's share of the PHEV and EV industry in the world, in terms of stock, increased from 0.5 percent in 2011 to 1.2 percent in 2018. This suggests Korea's effort to actively promote the NEVs. The market share of PHEVs and EVs in Korea's automobile market rose rapidly from 0.1 percent in 2014 to 2.2 percent in 2018 (IEA, 2019). Rechargeable battery is critical in the production of EVs and Korea has been one of the global leaders in the rechargeable battery production, which may enable Korea to become the leading producer of EVs. The current paper aims to overview the development of Korea's EV industry and to explain the government policies promoting it. Then, it draws implications from the industrial policy of Korea to promote the EV industry. The structure of this paper is as follows: Section 2 explains the development of Korea's automobile industry as a whole. Section 3 describes the role of the government in developing the EV industry in Korea. Section 4 derives policy implications from the case of Korea in the development of the EV industry. Conclusions are provided in section 5.

1) Business School, Seoul National University, Seoul 08826, South Korea.

2) Division of International Studies, Ewha Womans University, Seoul 03760, South Korea.

*Corresponding author: jsmah@ewha.ac.kr 


\section{Development of Automobile Industry of Korea}

Korea generated the first domestically produced car by assembling the components in 1955 (Korea Automobile Manufacturers Association (KAMA), 2005: 572-573). In the mid-1960s, the government enacted the Automobile Industry Protection Law, which provided the automobile industry in Korea with protection measures, such as prohibition of import of completed cars, exemption of tax to the producers and abolition of import tariffs subjected to the components (Green, 1992: 413-414). During the 1960s the automobile companies in Korea relied on the knock-down (KD) method for components assembly to produce automobiles. Tens of Korean engineers were trained in a Japanese automobile company, Nissan. Three companies, Hyundai, Kia and Shinjin (which became Daewoo several years later) produced automobiles in the late 1960s and 1970s by introducing foreign technologies or assembling components (Cho, 1997: 18-24, 37).

Targeting development of more value-added industries, the Korean government began to pursue the heavy and chemical industries (HCI) Promotion Plan in 1973-1974. As a part of the HCI Promotion Plan, the Korean government set the Automobile Industry Long-term Promotion Plan in May 1974. Since then, the government actively intervened in the process of automobile industry development in Korea. It set the goal of developing domestically produced economical cars with a local content ratio of over 95 percent and the target of producing more than 50,000 cars each year to gain from economies of scale (Oh, 1996). The Korean government, under the notion of import substitution, raised the local content requirement from 20 percent in the mid-1960s to over 90 percent by the end of the 1970s and encouraged the development of automobile components industry and independent automobile production technology (Green, 1992: 414). Furthermore, it raised the import tariff rate from 150 percent to 250 percent in 1974. Such a reform induced an increase in the government's tax revenue and the local demand for automobiles (KAMA, 2005: 202-203).

Recognizing the importance of components, the government required the automobile companies to establish factories producing important automobile parts (Lee and Mah, 2017: 231). The government declared to provide very generous tax incentives such as 50 percent reduction of excise tax and 67 percent reduction of automobile consumption tax as well as financial assistance for the first national car, meeting the requirements of the government. These motivated the automobile producers to produce their own brand model in the mid-1970s. In 1975, Hyundai Automobile established an integrated production plant in Yangsan ${ }^{1}$ and began to produce its own brand model, Pony, for the first time. The overall design of the production facilities was constructed by a Japanese automobile company Mitsubishi (Cho, 1997: 54-56). Although merely 37,000 cars were produced in Korea in 1975, the production increased to 378,000 cars in 1985 (Lee and Mah, 2017: 232).

In the early stage of production of its own brand model, Hyundai Automobile dumped its products in the international market to promote exports by setting the export price to be only about half of the domestic price. Low export price enabled Korea to record growth in the export of automobiles. Together with the increase in export, domestic consumption of automobiles increased rapidly in the late 1970s due to the reduction of automobile special consumption tax from 40 percent to 15 percent and the rapid economic growth during the 1970s. Domestic sales of automobiles increased from 35,000 cars in 1976 to 162,000 cars in 1979 . To acquire human capital needed in production, Hyundai Automobile sent about 200 engineers abroad to be trained in the foreign automobile companies (Cho, 1997: 49-56).

Korea's production of automobiles continued to increase during the 1980s. Production capacity of Hyundai Automobile increased to 300,000 cars in 1986 and enjoyed economies of scale in production. Import tariff rate imposed on car imports remained very high. In 1990, the import tariff rate on import of passenger cars fell from 50 percent to 20 percent and then to 8 percent in 1995 (Cho, 1997: 85, 175). Production of automobiles rose to 2.5 million cars in 1995, when Korea became the fifth largest automobile producer in the world. The number of cars produced in Korea exceeded 4 million during the 2010s (Lee and Mah, 2017: 232).

Domestic production of automobiles amounted to 4.7 million cars in 2011. Since then, the production fell approximately to 4.0 million cars in 2018 mainly attributable to the increase in production abroad. Table 1 shows the trend of productions and exports of automobiles of Korea during 1997-2018. Exports were recorded as 2.4 million cars in 2018, sharing three-fifths of domestic production. Export values amounted to US $\$ 64.0$ billion in the same year, accounting for 10.2 percent of total export values of Korea, US\$626.3 billion. Automobile industry accounted for 12.0 percent of value-added and 11.8 percent of employment in the manufacturing sector (KAMA, 2019; Statistics Korea, 2019a). Domestic production of Korea's automobiles shared 5.5 percent of the world production as a whole in 2010. Such a share of Korea's domestic production in the world automobile production decreased somewhat to 4.2 percent in 2018 (International Organization of Motor Vehicle Manufacturers, 2018; Statistics Korea, 2019a).

Table 1. Korea's Production and Exports of Automobiles, 2000-2018

\begin{tabular}{|c|c|c|c|c|c|}
\hline & 2000 & 2005 & $\begin{array}{l}\text { year } \\
2010 \\
\end{array}$ & 2015 & 2018 \\
\hline production (million units) & 3.1 & 3.7 & 4.3 & 4.6 & 4.0 \\
\hline exports (million units) & 1.7 & 2.6 & 2.8 & 3.0 & 2.4 \\
\hline export values (US\$ billion) & 15.3 & 38.0 & 54.4 & 71.3 & 64.0 \\
\hline automobile exports/total exports (percent) & 9.0 & 13.3 & 11.7 & 13.1 & 10.2 \\
\hline
\end{tabular}

Sources: Statistics Korea, The Trend of Automobile Industry, 2019; Bank of Korea, Economic Statistics, available at http://ecos.bok.or.kr (retrieved December 18, 2019)

${ }^{1}$ Yangsan neighbors the largest seaport in Korea, Busan seaport, and it takes about an hour to transport the products from Yangsan to Busan seaport. 
One of the most interesting phenomena which occurred in the global automobile industry during the 2010s is the rapid increase in productions and sales of eco-friendly vehicles. The eco-friendly new energy vehicles (NEVs) include EV, PHEV, Hybrid Electric Vehicle (HEV), and Fuel Cell Electric Vehicle (FCEV) (Korea Environment Corporation (KECO), 2019). Although the stock of eco-friendly NEVs in the world measured by PHEVs and EVs was only 1,890 units in 2005, it increased to 15.0 thousand units in 2010, to 1.3 million units in 2015 and to 5.1 million units in 2018 (International Energy Agency (IEA), 2019). It indicates the spectacular explosion of production and sales of NEVs in the world during the 2010s.

Table 2 shows the trend of stock of NEVs in major countries during 2009-2018. Sales of NEVs had been led by the US until the first half of the 2010s. For instance, in 2013, US explained 40 percent of the stock of NEVs in the world economy as a whole. US was followed by Japan until 2013. China's share in NEVs stock jumped since the mid-2010s, reaching 45 percent of the world economy as a whole, while the US' share fell to 22 percent in 2018. Korea accounted for only 1.2 percent of the stock of NEVs in 2018. Thus, Korea lags behind the other major automobile producers in terms of stock of NEVs. Meanwhile, the stock of NEVs, EVs and PHEVs particularly in Korea rose from 6,000 vehicles in 2015 to 59,600 vehicles in 2018 . The number increased by 10 times for just three years. The accumulated supply of four types of NEVs including hybrid cars increased rapidly from 184,000 vehicles in 2015 to 475,000 vehicles in 2018 (Ministry of Environment (MOE), 2019c: 39). So, focusing on 2015-2018 period, Korea's NEV industry appears to grow most rapidly among the major producers of automobiles.

Table 2. Stock of NEVs in Major Countries, 2009-2018

(unit: thousand)

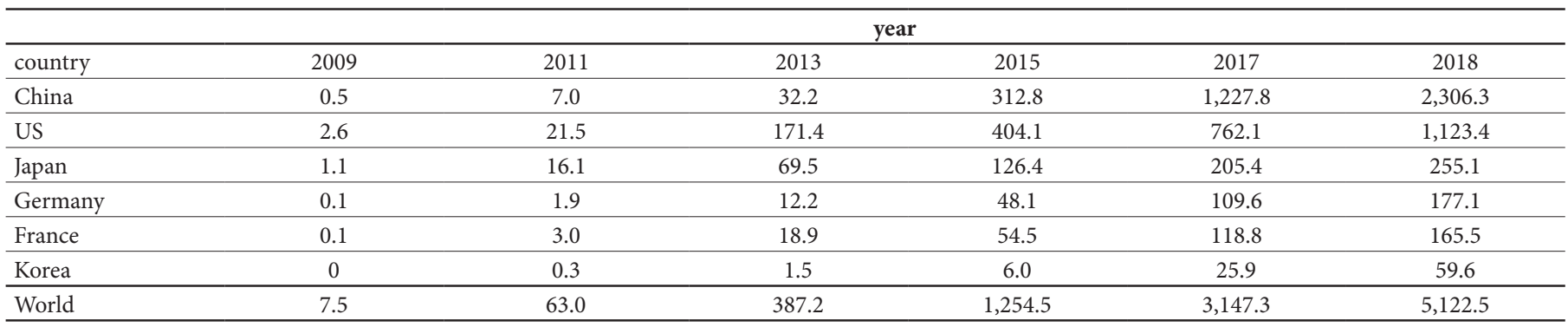

Note: NEVs in this Table comprise PHEVs and EVs.

Source: International Energy Agency, Global EV Outlook 2019, 2019

Table 3 shows the changing market share of EVs and PHEVs in several major countries. In 2018, the market share was over 4 percent in China and France. They were followed by US, Korea and Germany. Thus, Korea ranked the fourth in terms of market share of EVs and PHEVs. Korea's market share increased particularly from 0.3 percent in 2016 to 2.2 percent in 2018, showing that the NEVs market expanded most rapidly in Korea in the late 2010s.

Table 3. Market Share of EVs and PHEVs of Major Countries, 2010-2018 (unit: per cent)

\begin{tabular}{llllll}
\hline country & $\mathbf{2 0 1 0}$ & $\mathbf{2 0 1 2}$ & $\mathbf{2 0 1 4}$ & $\mathbf{2 0 1 6}$ & $\mathbf{2 0 1 8}$ \\
\hline China & - & 0.06 & 0.36 & 1.39 & 4.48 \\
France & - & 0.12 & 0.41 & 1.20 & 4.74 \\
Germany & 0.11 & 0.42 & 0.73 & 1.96 & \\
Japan & 0.06 & 0.01 & 0.04 & 0.07 & 0.10 \\
Korea & - & - & 0.12 & 0.34 & 2.21 \\
US & - & 0.43 & 0.77 & 0.98 & 2.45
\end{tabular}

Source: International Energy Agency, Global EV Outlook 2019, 2019

Despite relatively late development of the EV industry compared with its main competitors in the automobile market, both the government and the private automobile companies of Korea were aware of the importance of EVs in the future of the automobile industry as a whole. The government established the Natural Gas Bus Commercialization Project in 2000. In addition, policy grounds for supply of EVs were arranged in 2004 with the enactment of the Law on Environment Friendly Vehicle Development and Supply Promotion (KECO, 2019).
Even before the initiation of such projects prepared by the government, the private sector responded to the incoming trend in the automobile market rapidly. Two leading Korean automobile producers, Kia and Hyundai Motor Company, started to develop the non-commercial EVs since the late 1980s. They have been actively releasing new EV models (Cho, Kim and Yun, 2017: 107). Since 2004, Hyundai successfully developed hybrid vehicles with the support from the MOE in 2004 and tested them since then. Meanwhile, until the mid-2000s, Korea was obliged to rely heavily on import of core EV components such as motors and batteries due to the lack of appropriate technology. Hyundai and Kia Motors independently promoted domestic production of core automobile components for EVs and utilized domestically produced core components in producing EVs since 2009 (Kim, 2010: 31-32).

Table 4 shows that the number of NEVs registration has been constantly increasing in an exponential rate. For instance, the number of registered EVs rose from 66 in 2010 to 10,850 in 2016 and then to 72,814 in 2019. Despite the rapid increase in the number of NEVs during the 2000s, NEVs in Korea shared a mere 2 percent of the cumulative automobile supply of 23 million in 2018 (MOE, 2019c: 39). In 2017, the Korean government set a goal to reach 350,000 vehicles of registered EVs by 2022 (Office for Government Policy Coordination (OGPC) et al., 2017). 


\begin{tabular}{lrrrrr}
\hline & \multicolumn{2}{c}{ month year } & & \\
& Dec. 2010 & Dec. 2012 & Dec. 2014 & Dec. 2016 & Dec. 2018 \\
\hline EVs & 66 & 860 & 2,775 & 10,850 & 55,756 \\
HEVs & 19,167 & 75,003 & 137,522 & 233,216 & 405,084 \\
\hline
\end{tabular}

Source: Ministry of Land, Infrastructure and Transport (MOLIT) Statistic System, Total Registration Motor Vehicles, 2019

Table 5 shows the trend of international trade of automobiles in Korea. Although the total exports of automobiles decreased recently, exports of EVs have been increasing in general (KAMA, 2016). In 2017, Korea recorded trade surplus as much as US\$26 million in EV trade. This was possible as internationally competitive Korean EVs, such as Hyundai Ioniq Electrics and Kia Soul EV, were actively exported to the international market, while weak demand in domestic market led to decrease in imports (Ministry of Trade, Industry and Energy
(MOTIE), 2017: 223). In 2015-2017, exports of EVs exceeded US $\$ 300$ million each year. In addition, the share of EV export over automobile export significantly increased from less than 0.05 percent in 2002 to over 0.5 percent in 2017. Such a rapid increase indicates the growing importance of the EV industry. There was a modest increase in the share of EV import over the automobile import as a whole from 1.5 percent in 1997 to 9.2 percent in 2016.

Table 5. International Trade of Electric Vehicles and Automobiles as a Whole, 1997-2017

\begin{tabular}{|c|c|c|c|c|}
\hline Year & $\begin{array}{l}\text { export of EVs } \\
\text { (unit: US\$ } \\
\text { million) }\end{array}$ & $\begin{array}{c}\text { export of } \\
\text { automobiles } \\
\text { (unit: US\$ billion) }\end{array}$ & $\begin{array}{r}\text { import of EVs } \\
\text { au } \\
\text { (unit }\end{array}$ & import of \\
\hline 1997 & 0 & 12.8 & 0.3 & 2.1 \\
\hline 2000 & 0 & 15.3 & 0.0 & 1.8 \\
\hline 2005 & 0 & 38.0 & 0.1 & 4.7 \\
\hline 2010 & 4.6 & 54.4 & 0.6 & 8.5 \\
\hline 2015 & 339.5 & 71.3 & 20.4 & 15.5 \\
\hline 2016 & 315.2 & 65.7 & 14.7 & 6.0 \\
\hline 2017 & 340.7 & 64.8 & n.a. & n.a. \\
\hline
\end{tabular}

Note: HS Code for EV is 8703907000

Sources: Statistics Korea, Exports and Imports by Products, 2019; Statistics Korea, The Trend of Automobile Industry, 2017

\section{Industrial Policy of the Government to Promote the EV Industry}

The Korean government has taken various policy measures to promote the EV industry. The MOTIE is responsible for R\&D promotion and strengthening of the infrastructure such as EV charging stations. The MOE is in charge of commercialization of EVs and infrastructure through provision of subsidies. The MOLIT is concerned with setting safety standards for EVs. The OGPC coordinates different ministries (Hwang, 2015). Acknowledging the importance of EVs in development of the automobile industry and environmental protection, the Korean government announced a long-term goal of commercialization of EVs under the Fine Dust Management Comprehensive Countermeasures in 2017, which set the goal of distributing 350,000 EVs and 10,000 charging infrastructures for EVs by 2022, as is shown in Table 6 (OGPC et al., 2017: 18).

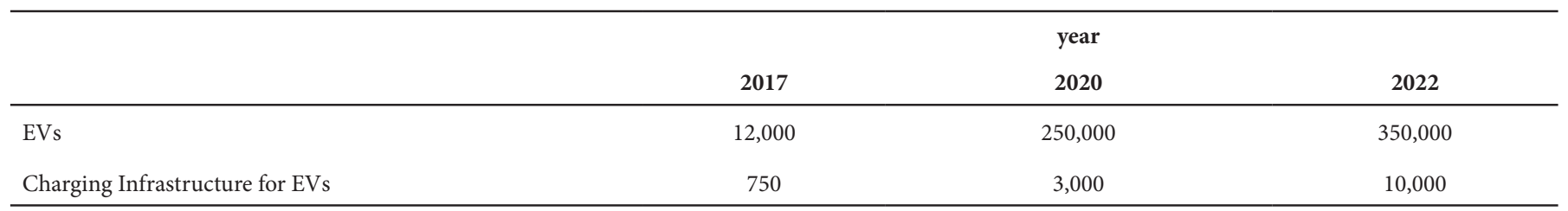

Source: OGPC et al., Fine Dust Management Comprehensive Countermeasures, 2017. 


\subsection{R\&D}

In the early 1990s, the Korean government initiated the Highly Advanced National (HAN) program, which was a large scale program to develop advanced technologies. It aimed to transform Korea into one of the leading seven countries in science and technology (Amsden, 2000). One of the $18 \mathrm{R} \& \mathrm{D}$ projects in the HAN program was the technological development of the next generation vehicle. Total of 19 governmental bodies and 709 private companies participated in the vehicle section of this project and more than 300 billion Korean won was allocated by both the government and private sector. The ultimate goal was to develop core technologies for NEVs that can meet the standard of environment and safety regulations of the advanced countries. The project led to upgrading Korea's EV technology level to the point where advanced types of EV components can be exported (Institute for Advanced Engineering (IAE), 2003: 234-235, 424).

Since 2004, Korea’s EV industry and its technology level developed under the government's R\&D promotion policy. In 2004, the Law for Eco-friendly Cars R\&D was enacted by the government for the development of environment-friendly vehicles industry. It could be considered as the first R\&D project in the EV industry in Korea (Hwang, 2015). The government established its R\&D project for EVs in 2011, which aimed at upgrading of EV technology, and collaborated with 45 research institutes and private companies (Lee, 2012: 7, 13). Along with this, in the same year, as a part of the Global Top Environment Technology Development Project, the government inaugurated the Center for Environmentally Friendly Vehicle (CEFV) to support technological development of EVs (MOE, 2015: 60). The R\&D project undertaken by CEFV started in 2011 and is planned to end in 2021, with an allocated budget of 100 billion Korean won, about US $\$ 90$ million, until the end of the project. It operates in a way that CEFV finances private/public companies and institutions to address specific R\&D tasks. CEFV developed technologies of automobile production that reduce carbon dioxide emission. Such development of technologies contributed to the Korean economy through export and domestic sales (CEFV, 2016).

In 2019, the government decided to provide R\&D expenditure in EVs to regions experiencing industrial crisis. It selected Jeollanam-do province as the beneficiary of the project. It would subsidize the selected small to medium-sized automobile components enterprises in the region with 17 billion Korean won, about US\$15 million, to be used for R\&D of EV parts and systems for 33 months (MOTIE, 2019b:1). Moreover, in the same year, the government initiated an R\&D project for the development of the technology of Micro EV, targeting small to medium-sized enterprises (SMEs). The government would allocate 8 billion Korean won, about US\$7 million, for about 3 years (KEIT, 2019).

For R\&D expenditure allocated to the energy-related industries including EVs over GDP, Korea recorded the highest level among the OECD members, recording 0.1 percent in 2014. However, such a high R\&D investment did not necessarily translate into satisfactory outcome (OECD, 2017: 32). ${ }^{2}$ Despite the R\&D efforts, compared to the other countries leading EV industry, Korea was regarded as having relatively low level of EV technology competitiveness as of 2016. If the technology level of the leading EV countries was scored as 100, Korea's technology level was estimated as 85 in 2016. Particularly in EVs material and components sector, Korea showed weaker competitiveness with the score of 71 . Such a low score in the material/automobile components sector of EV shows that Korea depends highly on imports of core materials used in batteries/motors (KEA, 2017: 176). This unsatisfactory performance of Korea's EV supports the claim made by OECD that Korea's high R\&D expenditure does not necessarily lead to advanced technology (OECD, 2017: 32).

R\&D in EVs appears to have improved significantly in the late 2010s. For instance, according to the Roland Berger's e-mobility index ${ }^{3}$ of 2018, as shown in Table 7, in terms of government's R\&D expenditure on EVs divided by GDP and EV technology level, Korea ranked the third, following France and Germany, among seven leading EV countries: France, Germany, Japan, US, China, Italy and Korea. Korea was ranked higher than the US and Japan. It shows the technological development in the EV industry accomplished by the Korean companies (Roland Berger, 2018: 5).

Table 7. E-mobility Index of 2018

(unit: points and per cent)

\begin{tabular}{lcc}
\hline country & $\begin{array}{c}\text { EV Technology } \\
\text { (out of 5 points) }\end{array}$ & $\begin{array}{c}\text { State R\&D on EV } \\
\text { (per cent of GDP) }\end{array}$ \\
\hline France & 2.9 & 0.044 \\
Germany & 2.2 & 0.008 \\
Korea & 2.1 & 0.006 \\
Japan & 1.8 & 0.003 \\
US & 1.8 & 0.001 \\
China & 0.9 & 0.001 \\
Italy & 0.2 & 0.000 \\
\hline
\end{tabular}

Source: Roland Berger, E-Mobility Index 2018, 2018

Note: EV technology is scored based on "current status of technology development in vehicles made by indigenous OEMs and the support for vehicle development provided by national subsidy programs."

Korea has the lowest co-invention rate with foreign partners among the OECD countries (OECD, 2017: 32). Korea is not a leading country in terms of the number of patents registered relating to EVs. In 2017, Korea had 8,015 patents registered relating to EVs, ranking fourth after China (26,246), US $(17,718)$, and Japan (10,932) (MOTIE, 2017: 205). During 2007 - 2016, the number of EV and EV-charging technology's patent application shows increasing trends. Such trend suggests that Korea's EV industry has experienced a constant technological development (KIPO, 2017: 4-5). Yet, Korea does not have significant global share of applied patents in the main areas of EV technology. China, Japan and US have most of the shares, whereas

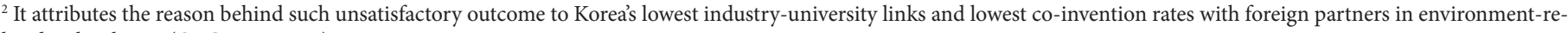
lated technologies (OECD, 2017: 32).

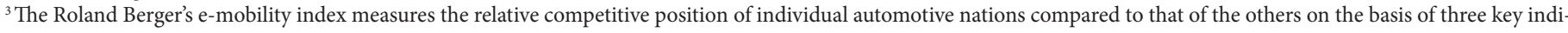
cators, i.e. technology, industry and market (Roland Berger, 2018: 18). 
Korea has only 1.4 percent of global share of related patents (MOTIE, 2017:213-218). During 2014 - 2016, there was a significant increase in the number of foreign EV-charging patent applications in Korea from 18.2 percent to 40.4 percent. Nevertheless, that of foreigners in EV technology patent applications in Korea remained relatively stable with 21.7 percent in 2016 (KIPO, 2017: 2-3, 6).

With all these R\&D investments, as of 2017, the level of Korean EVs technology is evaluated as similar to that of the other more developed EV producing countries such as US, Japan, Germany and France in some areas. Although there is certain technological gap in the material engineering field, Korea has the top-notch technology in the production of rechargeable battery, a core automobile component used in EVs (Cho, Kim and Yun, 2017: 108).

\subsection{Commercialization of EVs}

High price and inconvenience are the main bottlenecks to commercializing EVs. These bottlenecks were evidenced from the Hyundai's decreasing number of sales of the first HEV called Ioniq Hybrid in 2016. The reasons behind such a result were expensive purchase as well as maintenance cost, insufficient number of charging stations, and difficulties of repair services (Kang and Jeon, 2016: 17-18). There is significant difference in the price of EVs and gasoline vehicles. For instance, Hyundai's Kona EV is about 2.5 times more expensive than Kona gasoline vehicle as of 2019 (Naver Automobile, 2019). These significant price differences clearly suggest that EVs do not have price competitiveness against gasoline or diesel cars. To alleviate all these negativities of EVs, the Korean government has been actively implementing several policy measures to promote commercialization of EVs.

The government's provision of subsidies and tax cut in the EV industry enhances its price competitiveness, induces customers' purchase of the vehicles, and motivates suppliers' mass production of the vehicles by increasing profit margin (Lee, 2016: 3). The government sets its goal to commercialize 2 million NEVs by 2022 and plans to increase the demand for NEV by increasing price competitiveness and diversifying product lines through subsidies directed to the purchases of NEV and construction of its related infrastructure (MOE, 2019c).

The Korean government actively supports the development and commercialization of EVs by subsidizing private companies. In December 2010, the government established a goal to commercialize semimedium sized EVs by 2015, under the name "Green Car Roadmap", investing 70 billion Korean won, about US $\$ 60$ million. It set up the Ceremony of EV Commercialization 2012 to commercialize 2,500 EVs by 2012. Under the program it provided a direct subsidy of about 14 million Korean won, about US\$12,000, for the purchase of an EV, a subsidy of about 880,000 Korean won, about US\$750, for charging infrastructure and a tax cut for costs such as individual consumption, acquisition, and education (APEC, 2017: 19-20).
Under its motivation to mass supply EVs and to provide good driving experience for EVs compared to that of an internal combustion engine vehicle, MOTIE initiated policy measures focusing on two aspects. First, it provides significant amount of incentives for commercialization, and the policy measures include provision of purchase subsidy for each EV in $2016,{ }^{4}$ temporary exception of toll fees, discount of parking fees at public parking lots, establishment of new $\mathrm{EV}$ insurance that reduces the financial burden of the EV drivers and permission to use of bus-exclusive roads in highways for EV drivers. Second, it shows an effort to generate new channel of demand by increasing public institutions' mandatory EV purchase rate from 25 percent to 40 percent (MOTIE, 2016).

Although subsidies were provided to 25,600 EVs in 2018, they were distributed to 42,000 EVs in 2019 (MOTIE, 2019a: 3). In addition to subsidies, the government has also been providing various kinds of tax cuts not only for automobile tax, but also for individual consumption tax, education tax and acquisition tax, with cumulative maximum of 5.3 million Korean won, about US\$4,500, for EV, 2.7 million Korean won, about US\$2,300, for HEV, and 2.7 million Korean won, about US\$2,300, for PHEV as of 2019 (MOE, 2019c: 42).

Furthermore, the government's 2019 Plan for Mass Supply of Ecofriendly Vehicles provides significant amount of subsidies to individuals, companies, public institutions and local government who newly purchase NEVs aiming at reducing greenhouse gas. The plan provides purchase subsidies and discounts in tax, charging fee, parking fee, and high way toll fee to newly purchased NEVs (MOE, 2019b: 1-6). Under the project entitled 2019 Supply of EV and Construction of Charging Infrastructure, the government invests 462 billion Korean won, about US\$390 million. To encourage supply of EVs, the investment is distributed in the form of subsidy to EV producers and sellers; sellers discount EV price to the consumers and the discounted amount is subsidized by the government to the sellers. For construction of charging infrastructure, Korea Automobile Environmental Association provides subsidy to the suppliers of charging infrastructure (MOE, 2019a: 1-5).

The government plans to maintain all of the subsidies provided to purchase of EVs until 2022; meanwhile, considering the phase of technological development, it still leaves room for adjustment in the subsidy policy (MOTIE, 2018: 5). The Korean government views one of the problems of commercialization of NEVs as the insufficient amount of their charging stations (MOTIE, 2016). In 2010, Korea Electric Power Company (KEPCO) implemented generous EV-charging tariff that serves as an incentive to both the charging service providers and the customers. The tariff allowed the charging service providers to pay only the prime cost of electricity, and such an incentive led them to charge customers with only initial charger installation cost and operation fee (APEC, 2017: 20). Thus, it is clear that KEPCO, a state-owned enterprise, reduced the financial burden for both suppliers and buyers.

\footnotetext{
${ }^{4}$ As of December 2019, the amount of subsidy provided by the government to one purchasing an EV reaches up to 19 million Korean won, about US\$16,300 (Joong-Ang Sunday, 2019).
} 
Since 2011, the government has supplied EV charging infrastructure throughout apartments and areas with high accessibility such as supermarkets, parking lots and gas stations. The number of EV charging facilities increased from 29 facilities in 2011 to 2,283 facilities in 2018. This shows the government's successful implementation of policies regarding the EV charging infrastructure construction (MOTIE, 2016; MOTIE, 2018: 2-3).

Aside from tax cut and subsidy, the government has been strengthening environmental regulations to promote commercialization of EVs. In 2005, the government declared an administrative rule that obligates cities with severe level of air pollution to purchase certain proportion of low emission vehicles including EVs. The proportion has increased significantly from 1.3 percent in 2005 to 7.5 percent in 2011 and then to 12.0 percent in 2019 . Such a significant increase in the supply standard shows the Korean government's effort to commercialize EVs via strengthening of environmental regulations (Metropolitan Air Quality Management Office (MAMO), 2019). In addition, the government has its plan to implement the Low Carbon Vehicle Cooperation Charge System in 2020 which levies fine to the cars emitting high levels of carbon dioxide and provides subsidies to the cars emitting low levels of carbon dioxide, shifting the consumer demand from nonNEVs to NEVs. Accommodating such regulations, domestic automobile companies are focusing on developing technologies to increase fuel efficiency and reduce emission of carbon dioxide (Cho, Kim and Yun, 2017: 116-117, 129).

\subsection{Promotion of FCEVs and the Hydrogen Economy}

The Korean government announced the Roadmap for the Hydrogen Economy in January 2019 with its vision of achieving green growth through effective use of hydrogen as the main source of energy (MOTIE, 2019c: 3-4). Many countries emphasize the importance of moving toward the hydrogen economy due to its abundance and carbon dioxide-free nature; however, there are technological difficulties and high costs involved in processing hydrogen to be used effectively as the main source of energy (Kim, 2018: 1-2). Korea successfully developed its first FCEV in 2013, utilizing 99 percent of the domestically produced components in FCEV and accomplishing the world's longest FCEV mileage (MOTIE et al., 2019: 8).

Since Korea has its competitiveness in FCEVs and hydrogen fuel cell, the Korean government decided to keep these fields in the center of the roadmap for the hydrogen economy. More precisely, the industrial policy targeting FCEVs in the roadmap mainly focuses on two areas: increase of FCEVs supply and development of hydrogen energy technologies. For the supply part, the government has adjusted its aim for the supply of FCEVs and the charging infrastructures (MOTIE et al., 2019: 18-19). It set a goal to supply 81,000 FCEV s and 310 charging stations in 2022, and 6.2 million FCEVs and 1,200 charging stations in 2040 (MOTIE, 2019c: 11). In addition, the government has drafted an R\&D project whose budget amounts to 300 billion Korean won, about US $\$ 260$ million, to fully localize core components of FCEVs by 2022.

\section{Conclusion and Policy Implications}

The role of the government has been critical in the development EV industry of Korea. Considering the significant difference between EVs and the traditional gasoline/diesel cars, the Korean government has actively implemented R\&D promotion policy and measures to promote commercialization of EVs including provision of subsidies, tax incentives and infrastructure. According to the Korean government, due to such subsidization, tax incentives and provision of infrastructure, the cost of purchasing and charging/fuel expenses for EVs altogether for five years is estimated to be smaller than that of internal combustion automobiles (MOE, 2017: 11).

It has been known that there are three weaknesses of EVs: short driving mileage without recharge, high price, and insufficient supply of recharging facilities (Hankyore Newspaper, 2019). Modern development of technologies enabled the driving mileage without recharge as long as 277 kilometers for Hyundai Ioniq, 385 kilometers for Niro EV, and 406 kilometers for Kia Kona EV as of late 2019 (Joong-Ang Sunday, 2019). Therefore, the first weakness of EVs appears to have been remedied. To remedy the second and the third weaknesses of EVs, the Korean government has provided subsidies and established recharging facilities. It planned to raise the number of the public rapid rechargers for EVs from 5,390 units in October 2019 to 10,000 units in 2022 and then to 15,000 units in 2025 (MOTIE, 2019d). Thus, as of February 2020, it appears that most important weaknesses of EVs appear to be mostly removed.

The industrial policy of the Korean government to promote the EV industry provides important implications to the automobile producers. First, the traditional gasoline car market has been led by several leading producers in Japan, western Europe, and the US. Some developing countries such as China, Korea, India and Mexico entered the market and currently share a great proportion in the global automobile market. The other developing countries have also been increasing their production capacities. This means that technologies needed in producing gasoline cars have been acquired by new entrants in the automobile market. In addition, facing the threat of global warming, demand for eco-friendly cars has increased. Production of EVs, however, requires advanced technologies. Therefore, the leading producers of automobiles appear to be heading to take the rising market earlier than the others. The Korean government together with some of the other major producers also realized the importance of EVs and allocated substantial amount of resources to develop technologies and expand the production scale of private companies. The major producers of automobiles not developing EV production technologies may lag behind in the global automobile market.

Second, R\&D efforts are likely to lead to development of advanced technologies in technology-intensive industries such as the EV industry. Therefore, the government and automobile producing companies of Korea continued to raise R\&D expenditure to develop EVs. Although Korea's R\&D expenditure allocated to the energy-related 
industries including EVs over GDP is very high, its performance has been not so satisfactory. This indicates that the government as well as the private automobile producing companies should try to improve the efficiency of their R\&D activities in EVs.

Third, in the early stage of development of the automobile industry in the 1970s and 1980s when Korea did not have the advanced automobile production technology, the Korean government successfully arranged technology licensing from foreign automobile countries that allowed the automobile producers to learn from advanced countries (Lee and Mah, 2017: 234). Like Korea's early developmental phase in automobile production, it may be effective for the less advanced EV producers to utilize technology licensing or other forms of cooperative projects with foreign producers with more advanced technology in the EV industry.

Fourth, rechargeable battery is a critical component in an EV particularly in the sense of lengthening the driving mileage without recharging electricity. Korea, similar to China, is one of the leading countries in production of rechargeable batteries. It would be helpful for the Korean EV producers to strengthen cooperation with the Korean rechargeable battery producers, and more or less the same for the other countries which are leading production in both EVs and rechargeable batteries.

Fifth, high unit price level has been one of the critical weaknesses of EVs regardless of the countries. To reduce the burden that should be borne by the consumers, the Korean government as well as the governments of the other countries have provided various kinds of subsidies and tax incentives to purchase of EVs. Such subsidies and tax incentives are expected to disappear a few years later. Therefore, success or failure of the EV industry will depend on the probability of reducing the production cost and price level of EVs.

Sixth, more than thousands of components are needed in production of EVs. Therefore, there may be an important role for SMEs having advanced technologies in certain components. Meanwhile, the amount of R\&D subsidy programs targeting SMEs producing components of EVs is not so substantial in case of Korea. Therefore, it would be needed for the government to prepare R\&D support measures targeting promotion of SMEs, venture businesses in particular, in the EV industry.

Seventh, different Ministries are likely to have quite different positions with respect to the same issue. It is particularly the case of an issue relating to environmental protection and economic growth. Promotion of the EV industry is one of such issues. The conflict between a Ministry in charge of environmental protection and the other Ministry promoting industrial-led economic development may delay the decision and implementation of the concerned policies. To avoid conflicts reducing efficiency of the government policy, the government wishing to promote the EV industry should define the responsibility of each Ministry precisely and establish a system that can resolve conflicts between the Ministries concerned efficiently.

\section{References}

Amsden, A. (2000). Industrialization in the New WTO Era, Paper to the UNCTAD High. Level Round Table on Trade and Development: Directions for the Twenty-first . Century, Bangkok, 12 February.

APEC. (2017). The Impact of Government Policy on Promoting New Energy Vehicles. (NEVs) - The Evidence in APEC Economies (Report No. APEC\#217-CT-01.3). Beijing: CTI Sub-Fora and Industry Dialogues Groups, Automotive Dialogue.

Bank of Korea. (2019, December 18). Economic Statistics, Retrieved from http://ecos.bok.or.kr.

Center for Environmentally Friendly Vehicle (CEFV). (2016). Center for Environmentally

Friendly Vehicle. Retrieved from https://www.cefv.re.kr (in Korean).

Cho, C. (1997). Development and Growth Potential of Korea's Automobile Industry . (Research Report Vol. 386). Korea Institute for Industrial Economics \& Trade. (in Korean).

Cho, C., Kim, K. Y. and Yun, J. Y. (2017). NEVs Policy Evaluation and Direction for Its. Improvement. Research Report 2017-844. Korea Institute for Industrial Economics and Trade (in Korean).

Green, A. (1992). South Korea's Automobile Industry: Development and Prospects. Asian. Survey, 32(5), 411-428.

Hankyore Newpaper. (2019, October 23). The Best Technologies that Leads to Production of Electric Vehicles Batteries.

Hwang, S. (2015). Comparative Study on Electric Vehicle Policies between Korea and EU Countries. World Electric Vehicle Journal, 7.

Institute for Advanced Engineering (IAE). (2003). A Study on the Highly Advanced National

(HAN) Program Evaluation II. Retrieved from http://www. ndsl.kr/ndsl /search/detail/report/reportSearchResultDetail. do?cn=TRKO200400000989. International Energy Agency (IEA). (2019). Global EV Outlook 2019. IEA. Paris.

Retrieved from www.iea.org/publications/reports/globalevoutlook2019/ International Organization of Motor Vehicle Manufacturers (OICA). (2018). Production Statistics. Retrieved from http:// www.oica.net/production-statistics/

Joong-Ang Sunday. (2019, December 14). Electric Vehicles Slowing Down in the Winter. Season (in Korean).

Kang, C. and Jeon, S. (2016). Expansion of NEVs, Truth and False. Issue \& Analysis 255. Gyeonggi: Gyeonggi Research Institute (in Korean). 
Kim, H. (2010). Direction of NEVs' technological development. Science and Technology. Policy, 178(20), 28-33 (in Korean).

Kim, J. K. (2018). Policy Research for the Production of Eco-friendly CO2-free Hydrogen. (Research Report 18-06). Korea Energy Economics Institute: Ulsan (in Korean).

Korea Automobile Manufacturers Association (KAMA). (2005). 50 years journey of Korea's automobile industry. Retrieved from http://www.kama.or.kr/InfoController (in Korean).

Korea Automobile Manufacturers Association (KAMA). (2016). International comparison of automobile industry's export competitiveness. Retrieved from http://www.kama.or.kr/jsp/webzine/201610/ pages/issue_03.jsp (in Korean).

Korea Automobile Manufacturers Association (KAMA). (2019, August 8). Statistical Database, Retrieved from http://www.kama.or.kr.

Korea Electronics Association (KEA). (2017). Current States and Issues of Automobile (in Korean).

Korea Environment Corporation (KECO). (2019, May 29). Electric Vehicles - Characteristics of Electric Vehicles. Retrieved from https:// www.ev.or.kr/portal /ecocar?pMENUMST_ID=21539 (in Korean)

Korea Evaluation Institute of Industrial Technology (KEIT). (2019, May 29). Notice of 2019. Automobile Industry (Autonomous Vehicles and Electric Vehicles) Support Plan. Retrieved from https://itech.keit.re.kr.

Korea Intellectual Property Office (KIPO). (2017). Era of Electric Vehicle Approaches, Patents for Electric Vehicle Charging Technology Should Be Actively Acquired. Retrieved from https://www.gov.kr/portal/ntnadmNews/1270709 (in Korean).

Lee, J. I. and Mah, J. S. (2017). The role of the government in the development of the automobile industry in Korea. Progress in Development Studies, 17(3), 229-244.

Lee, Sn. (2012). Analysis of RßD for Electric Vehicles in Major Countries. National IT Industry Promotion Agency (NIPA) (in Korean).

Lee, T. (2016). Growth of Electric Vehicle Market via Policies and Restrictions. KB. Financial Group Inc. Business Research Institute (in Korean).

Metropolitan Air Quality Management Office (MAMO). (2019). 2019 Annual Supply Standard for NEVs-Seoul Metropolitan Area Air Quality Management Office Notification Vol. 2019-4. Sejong-si: Ministry of Environment (in Korean).

Ministry of Environment (MOE). (2014). Era of NEVs - Achievements and Strategies. Sejong-si: MOE (in Korean).

Ministry of Environment (MOE). (2015). NEVs - Hybrid Vehicles, Plug-in Hybrid Electric Vehicles, Electric Vehicles, Fuel Cell Electric Vehicles. Sejong-si: MOE (in Korean).
Ministry of Environment (MOE). (2017). Purchase Guide for NEVs. Retrieved from http://www.me.go.kr/mamo/web/board/read.do?me nuId=575\&boardId=822150\&boardMasterId=187\&condition .hideCate $=1$ (in Korean).

Ministry of Environment (MOE). (2019a). 2019 Project for Electric Vehicle Supply and Charging Infrastructure Construction - Instructions for Subsidy Provision. Sejong-si: MOE (in Korean).

Ministry of Environment (MOE). (2019b). 2019 Plan for NEVs Supply. Sejong-si: MOE (in Korean).

Ministry of Environment (MOE). (2019c). Eco-friendly Automobiles. Sejong-si: MOE (in Korean).

Ministry of Land, Infrastructure and Transport (MOLIT). (2019). Total Registration Motor Vehicles.

Ministry of Trade, Industry and Energy (MOTIE). (2016). Electric Vehicles, Fuel Cell Electric Vehicles - $10^{\text {th }}$ Conference on Trade and Investment Promotion. Sejong-si: MOTIE (in Korean).

Ministry of Trade, Industry and Energy (MOTIE). (2017). 2017 Research on Electric Vehicle Industry's Competitiveness. Sejong-si: Ministry of Trade, Investment and Energy (in Korean).

Ministry of Trade, Industry and Energy (MOTIE). (2018). Policy Direction for Increasing Supply of Electric Vehicles and Fuel Cell Electric Vehicles. Ministerial Conference on Innovation and Growth (in Korean).

Ministry of Trade, Industry and Energy (MOTIE). (2019a). Monthly Trends of Domestic Automobile Industry in April 2019 for Environment-Friendly Vehicles. Sejong-si: MOTIE (in Korean).

Ministry of Trade, Industry and Energy (MOTIE). (2019b). 2019 Notification of a Plan to Develop Auto Parts for Future Electric Vehicles in Industrial Crisis Areas. Sejong-si: MOTIE (in Korean).

Ministry of Trade, Industry and Energy (MOTIE). (2019c). Announcement of the Government's Roadmap for Activation of Hydrogen Economy. Retrieved from http://www.korea.kr/news/pressReleaseView. do?newsId=156313559 (in Korean).

Ministry of Trade, Industry and Energy (MOTIE). (2019d). The Strategy for Development of the Future Automobile Industry. October 2019.

Ministry of Trade, Industry and Energy (MOTIE) et al. (2019). Roadmap for Activation of Hydrogen Economy (in Korean).

Naver Automobile. (2019, August 1). Retrieved from https://auto.naver. com/cmpr/cmprResult.nhn?yearsId=124423,130617,124705,119407. OECD. (2017). OECD Environmental Performance Reviews: Korea 2017. OECD: Paris (in Korean).

Office for Government Policy Coordination (OGPC) et al. (2017). Fine Dust Management Comprehensive Countermeasures (in Korean). 
Oh, W. C. (1996). Korean Type of Economic Construction, Vol. 4, Kia Motors Research Institute, 1996 (in Korean).

Roland Berger. (2018). E-mobility Index 2018. Roland Berger GmbH and Forschungsgesellschaft Kraftfahrwesen mbH Aachen, Germany.
Statistics Korea. (2019a, August 8). The Trend of the Automobile Industry (in Korean). Retrieved from http://www.index.go.kr/potal/ main/EachDtlPageDetail.do?idx_cd= 1150 .

Statistics Korea. (2019b). Import and Export of Goods. Korea International Trade Association. Retrieved from http://stat.kita.net/stat/ kts/pum/ItmImpExpList.screen (in Korean). 